\title{
ANALISIS PEDAGOGICAL CONTENT KNOWLEDGE GURU DAN CALON GURU SD PADA PEMBELAJARAN MATEMATIKA
}

\author{
Christine Iriane Gultom ${ }^{1}$, Helti Lygia Mampouw ${ }^{2}$ \\ ${ }^{1,2}$ Universitas Kristen Satya Wacana Salatiga, Jl. Diponegoro No.52-60, Salatiga, Sidorejo \\ 202015078@student.uksw.edu
}

\begin{abstract}
Pedagogical Content Knowledge (PCK) is an important thing that must be mastered by teachers and prospective teachers to find out how to teach certain content to improve student understanding. The purpose of this research was to analyze the pedagogical content knowledge of teachers and prospective teachers in elementary in mathematics learning. The research method is descriptive qualitative. The focus of this research is the Wiyata Bakti teacher at SD Kaligentong 01 Ampel and prospective primary school teacher. The method of data collection in this research uses questions and interviews consisting of questions that are used to collect data relating to 7 components of PCK. The results of this research indicate that the PCK owned by the teacher is good in mathematics learning and PCK owned by prospective teacher is good enough in mathematics learning.
\end{abstract}

Keywords: Teacher and Prospective Teacher of Elementary School, Mathematics, Pedagogical Content Knowledge

\begin{abstract}
Abstrak
Pedagogical Content Knowledge (PCK) merupakan hal penting yang harus dikuasai oleh guru dan calon guru untuk mengetahui bagaimana mengajarkan konten tertentu untuk meningkatkan pemahaman siswa. Tujuan penelitian ini untuk menganalisis pedagogical content knowledge guru dan calon guru SD pada pembelajaran matematika. Metode penelitian yang digunakan adalah deskriptif kualitatif. Fokus penelitian ini adalah guru wiyata bakti di SD Kaligentong 01 Ampel dan calon guru. Metode pengumpulan data pada penelitian ini menggunakan soal dan wawancara yang terdiri dari butir-butir pertanyaan yang dipergunakan untuk mengumpulkan data yang berkaitan dengan 7 komponen PCK. Hasil penelitian ini menunjukkan bahwa PCK yang dimiliki guru sudah baik dalam pembelajaran matematika dan PCK yang dimiliki calon guru cukup baik dalam pembelajaran matematika
\end{abstract}

Kata Kunci: Guru dan Calon Guru SD, Matematika, Pedagogical Content Knowledge

Guru merupakan tenaga kependidikan yang berperan penting dalam keberlangsungan proses belajar mengajar dengan salah satu tugas utama guru adalah mendidik. Beberapa tugas utama guru berdasarkan KEMENDIKBUD Nomor 15 tahun 2018 adalah mendidik, mengajar, dan mengevaluasi peserta didik. Turnuklu \& Yesildere (2007) menyatakan bahwa beberapa faktor dapat mempengaruhi pengajaran tetapi guru memegang peran penting dalam proses pengajaran. Selain itu, calon guru juga memiliki peran penting dalam pembelajaran. Rusilowati, dkk (2012) bahwa calon guru perlu dibekali keterampilan agar dapat memberdayakan siswa.

Berdasarkan hasil Uji Kompetensi Guru pada tahun 2015 sampai 2017, nilai rerata guru masih dibawah nilai standar (Paramita, 2018). Hal ini menunjukkan kurangnya kualitas guru dalam proses pembelajaran. Selain itu, sebagian siswa mengeluh dengan pengajaran guru yang kurang menarik, khususnya pada pembelajaran matematika. Sejalan dengan pendapat Nurhidayah (2016) bahwa siswa cenderung bosan dalam pembelajaran matematika karena kurangnya inovasi pembelajaran yang 
diberikan guru, padahal matematika sangat penting untuk dipelajari.

Kurangnya kualitas guru dalam proses pembelajaran menandakan bahwa guru belum sepenuhnya menguasai stardar kompetensi utama yang ditetapkan oleh PERMENDIKNAS Nomor 16 tahun 2007 meliputi kompetensi pedagogik, profesional, sosial dan kepribadian. Dalam hal ini kompetensi pedagogik dan profesional dianggap lebih efektif dalam pembelajaran. Kompetensi pedagogik merupakan kemampuan guru dalam pengelolaan pembelajaran peserta didik yang sekurang-kurangnya meliputi pemahaman peserta didik, perencanaan dan pelaksanaan pembelajaran, evaluasi hasil belajar, pemanfaatan teknologi pembelajaran dan pengembangan peserta didik untuk mengaktualisasikan berbagai potensi yang dimilikinya (Sanjaya, 2010: 279). Sedangkan kompetensi profesional adalah kompetensi atau kemampuan yang berhubungan dengan penyelesaian tugas-tugas guru (Sanjaya, 2006: 144).

Salah satu penelitian yang banyak membahas tentang kompetensi pedagogik dan kompetensi profesional secara serentak adalah Pedagogical Content Knowledge (PCK). PCK adalah pengetahuan yang dikembangkan guru melalui pengalaman tentang bagaimana mengajarkan konten tertentu untuk meningkatkan pemahaman siswa (Purwaningsih, Rustaman \& Redjeki, 2010). Menurut Shulman (1986) PCK merupakan hal penting yang harus dikuasai oleh setiap guru karena guru harus memiliki pemahaman yang mendalam tentang suatu materi yang akan disampaikan kepada siswa. Wulandari dan Iriani (2018) menyatakan bahwa pengembangan PCK dapat meningkatkan kompetensi pedagogik dan kompetensi profesional yang dimiliki oleh guru. Selain guru, calon guru juga perlu memperhatikan kemampuan PCK yang dimilikinya sebelum memasuki dunia pendidikan. Hal ini didukung oleh Maryono (2016) bahwa calon guru perlu menyiapkan diri sebagai sosok guru profesional dengan melihat PCK yang dimilikinya.

Berkaitan dengan PCK yang bertujuan mentransferkan ilmu pengetahuan, Sekolah Dasar merupakan tempat awal yang harus diperhatiakn guru dalam mengenalkan ilmu pengetahuan dasar kepada siswa. Oleh karena itu, penelitian ini bertujuan untuk menganalisis pedagogical content knowledge (PCK) guru dan calon guru pada pembelajaran matematika.

\section{METODE}

Penelitian ini merupakan penelitian deskriptif kualitatif, karena penelitian ini dilakukan dengan menganalisis PCK Guru dan Calon Guru SD dalam pembelajaran matematika. Subjek penelitian berjumlah 2 orang yang terdiri dari 1 orang perempuan berinisial S1 dan 1 orang laki-laki berinisial S2. Subjek S1 adalah guru wiyata bakti di SD Kaligentong 01 Ampel dan subjek S2 adalah calon guru SD. Pemilihan subjek diperoleh dari data nilai IPK yang dikatergorikan sehingga terpilih subjek pada kategori tinggi. Subjek dari kategori tinggi karena dimungkinkan memiliki kemampuan PCK yang lebih baik.

Instrumen dalam penelitian ini terdiri dari instrumen utama yaitu peneliti sendiri dan istrumen bantu berupa pedoman wawancara dan soal tes matematika. Pedoman wawancara terdiri dari 7 
komponen PCK yaitu pengetahuan tentang kurikulum, penilaian, mengajar, siswa, sumber daya, tujuan dan materi. Soal tes terdiri dari 2 kategori yaitu kelas rendah dan kelas tinggi masing-masing 2 soal tentang bilangan dan geometri. Teknik analis data yang digunakan adalah dengan tiga langkah analisis data kualtatif berupa reduksi data, penyajian data dan verifikasi atau penarikan kesimpulan.

\section{HASIL PENELITIAN}

\section{Pengetahuan tentang Kurikulum}

Berdasarkan pengalaman yang dimiliki subjek S1 ketika masih dibangku Sekolah Dasar, pembelajaran menggunakan KTSP dirasa lebih maksimal karena dilakukan per mata pelajaran sehingga materi yang diajarkan lebih fokus, rinci dan terarah. Subjek S1 mengatakan bahwa: "Menurut aku yah, lebih enak mengajar KTSP. Kenapa? Karena kita bisa lebih fokus. Misal, anakanak belajar IPA, yah udah kita bahas IPA, anak-anak belajar matematika yah udah fokus matematika". Hal ini menunjukkan bahwa subjek S1 telah mengetahui perbedaan kurikulum KTSP dan Kurikulum 2013 tematik sehingga subjek dapat menentukan kurikulum yang baik untuk diterapkan menggunakan KTSP dalam pembelajaran dibandingkan Kurikulum 2013 tematik.

Subjek S2 merasa pembelajaran menggunakan Kurikulum 2013 tematik jauh lebih efisien karena dalam 1 pembelajaran dapat mencakup 3 mata pelajaran sekaligus, sehingga dapat mempermudah guru dalam pembuatan RPP meskipun terdapat tantangan yaitu ketika guru harus berpindah dari mata pelajaran satu ke mata pelajaran lainnya tanpa memberitahukan ke siswa bahwa mata pelajaran tersebut sedang di arahkan ke mata pelajaran lainnya. Subjek S2 menyatakan bahwa: "Perbedaannya K13 itu lebih terindentifikasi, RPPnya itu mencakup berbagai mata pelajaran sedangkan KTSP itu hanya meтиat 1 mata pelajaran. Kalau aku pribadi lebih enak K13 soalnya kita sekali ngajar bisa dapat beberapa mata pelajaran. Tapi itu pasti ada tantangannya, seperti kalau kita mau pindah mata pelajaran kita harus mencari ide atau sesuatu untuk menghubungkan ke mata pelajaran selanjutnya tanpa menyebutkan mata pelajaran tersebut”. Hal ini menunjukkan subjek S2 lebih menyukai penggunaan Kurikulum 2013 tematik dibandingkan dengan KTSP.

Subjek S1 menentukan tujuan pembelajaran pada RPP dengan menguraikan indikator dan mengaitkannya pada kehidupan sehari-hari sehingga siswa dapat mengaplikasikan apa yang sudah dipelajari. Namun dalam melaksanakan kegiatan pembelajaran sering kali tidak sesuai dengan apa yang dibuat pada RPP contohnya adalah alokasi waktu. Subjek S1 menyatakan bahwa: "Oh, tujuan pembelajaran itu kan kita turunkan dari indikator toh, yah udah jadi kita kalau bikin tujuan kita acuannya indikator ... Tapi yah gitu, sebagai guru pintar-pintar memanage waktu atau memperhitungkan waktu”. Hal ini menunjukkan bahwa subjek S1 mengetahui struktur pembuatan RPP yang mengacu pada Kurikulum 2013 tematik dengan mengaitkan pembelajaran pada kehidupan sehari-hari.

Dalam pembuatan RPP oleh subjek S2, terdapat beberapa hal yang harus dipertimbangkan salah satunya alokasi waktu yang tepat sehingga tujuan pembelajaran pada suatu materi dapat tercapai 
semua. Subjek S2 mengetahui bahwa tujuan pembelajaran yang akan dicapai harus berpedoman pada indikator agar lebih terarah dan meminimalisir waktu pembelajaran sehingga lebih efisien. Subjek S2 menyatakan bahwa: "Pasti ada, yang pertama itu materi yang akan kita ajarkan dengan waktu yang digunakan. Misalkan kita mau mengajar hari senin, kan ada upacara juga, pasti kurang waktunya. Nah sekarang kita mengacu pada tujuan pembelajaran, kadang kita membuat tujuan pembelajaran terlalu banyak pasti diingatkan sama guru kelasnya karena nanti tidak akan mencukupi waktunya. Jadi yang harus lebih di perhatikan itu tujuan pembelajaran dan kegiatan pembelajaran supaya bisa menyesuaikan dengan waktunya". Hal ini menunjukkan bahwa subjek S2 mengetahui struktur pembuatan RPP yang mengacu pada Kurikulum 2013 tematik dengan menyesuaikan tujuan pembelajaran dengan alokasi waktu.

\section{Pengetahuan tentang Penilaian}

Subjek S1 melakukan proses penilaian sosial, sikap dan keterampilan menggunakan rubrik yang terdiri dari beberapa indikator. Penilaian pengetahuan dilakukan menggunakan soal tes tertulis. Subjek S1 menggunakan jenis tes tertulis berupa pilihan ganda, isian singkat dan uraian. Subjek S1 menyatakan bahwa: "Jadi dalam melakukan penilaian, yah kita kalau menilai pengetahuan kan kita menggunakan tes. Kalau efektif dan keterampilan kita ada rubrik dan indikator-indikatornya, ... tesnya berupa pilihan ganda, isian singkat dan uraian". Hal ini menunjukkan bahwa subjek S1 memahami struktur penilaian pada setiap aspek penilaian.

Subjek S2 menggunakan jenis tes tertulis berupa isian singkat dan uraian yang berpedoman dari buku pegangan guru. Pada penilaian sikap, keterampilan dan spiritual, subjek S2 menggunakan lembar penilaian yang sudah dibuat rubri-rubriknya. Subjek S2 menyatakan bahwa: "Kalau kita dulu milih itu berdasarkan buku pegangan guru, kan kebanyakan dibuku itu soal isian singkat dan uraian ... jadi, misalkan dalam penilaian sikap, keterampilan dan spiritual itu (lembar penilaian) yang sudah ada rubrik penilaiannya". Hal ini menunjukkan bahwa subjek S2 memahami struktur penilaian pada setiap aspek penilaian.

Subjek S1 mengadakan remedial untuk siswa yang nilainya dibawah standar kelulusan agar dapat memperbaiki nilai. Sedangkan untuk siswa yang sudah mencapai nilai standard kelulusan diberikan pengayaan agar memantapkan pemahaman siswa terhadap suatu materi. Subjek menyebutkan bahwa: "Kesempatan untuk siswa yang belum tuntas, makanya perlu diadakannya remidi. ... Pengayaan ikutnya kan sudah tuntas nilainya, jadi pengayaan itu seperti latihan lagi atau pemantapan”. Hal ini menunjukkan bahwa subjek S1 memberikan kesempatan kepada siswa untuk memperbaiki nilai.

Subjek S2 mengadakan remedial dan pengayaan dengan tujuan untuk memotivasi siswa agar memperoleh nilai yang lebih baik dari sebelumnya. Subjek mengatakan bahwa: "Remedial dan pengayaan itu tujuannya untuk memotivasi siswa yang kurang itu agar mau mencapai titik yang lebih tinggi lagi”. Hal ini menunjukkan bahwa subjek S2 memberikan kesempatan kepada siswa untuk mendapatkan nilai yang lebih tinggi dari sebelumnya. 


\section{Pengetahuan tentang Mengajar}

Subjek S1 menekankan pada model pembelajaran konvensional yang di lakukan dengan ceramah. Proses mengajar berlangsung secara ceramah variatif salah satunya seperti mendongeng. Subjek S1 menyatakan bahwa: "Banyak yang bilang kalau model ceramah itu model yang konvensional. Tapi menurut ku, sekarang anak-anak itu lebih suka kalau kita mendongeng dulu. Jadi, kita itu tidak bisa lepas dari yang namanya ceramah kalau ngajar. Tinggal kita variasinya gimana, agar ceramah kita tidak membosankan”. Hal ini menunjukkan bahwa subjek S1 memberikan pengajaran dengan menyesuaikan keadaan siswa.

Subjek S2 menekankan pada model pembelajaran diskusi kelompok namun seringkali memiliki kendala pada penguasaan kelas. Model pembelajaran diskusi kelompok hanya dilakukan subjek S2 untuk proses pembelajaran, sedangkan untuk evaluasi akhir pembelajaran dilakukan menggunakan mind mapping. Hal ini di dukung oleh pernyataan "Kita akhirnya menggunakan metode diskusi, dulu bentuk kelompoknya kita bentuk sendiri dengan tukaran teman sebangku depan belakang karena kalau hitungan gitu biasa ribut dan memakan waktu" dan "Kita waktu ngajar itu kekurangannya dipenguasan kelompok". Hal ini menunjukkan bahwa subjek S2 memberikan pengajaran dengan menyesuaikan model pembelajaran.

Pemberian motivasi yang dilakukan oleh subjek S1 seringkali dilakukan pada saat awal dan akhir pembelajaran namun tidak menutup kemungkinan jika motivasi dilakukan ditengah proses pembelajaran. Tujuan diberikan motivasi agar siswa semangat untuk mengikuti pembelajaran. Motivasi yang diberikan oleh subjek S1 berupa reward, pujian, applause, ice breaking dan lain-lain. Subjek menyatakan bahwa: "Diawal mereka dikasih motivasi agar mereka semangat untuk mengikuti pembelajaran, kalau diakhir motivasinya mereka di kasih nasehat seperti harus rajin belajar. ... memberikan reward, pujian, applause, mereka sudah bosan aku berikan ice breaking”. Hal ini menunjukkan bahwa subjek S1 memberikan motivasi sesuai kebutuhan siswa dalam pembelajaran.

Subjek S2 memberikan motivasi selama proses pembelajaran berlangsung sesuai dengan kebutuhan. Tujuannya diberikan motivasi agar siswa semangat untuk mengikuti pembelajaran. Motivasi yang diberikan oleh kedua subjek seringkali berupa reward, pujian, dan ice breaking. Subjek menyatakan bahwa: "Kalau motivasi itu bisa kapan saja, supaya siswa itu waktu belajar bisa lebih semangat intinya. ... Kadang kita juga beri reward dan pujian. ... Ice breaking itu sih pasti yah". Hal ini menunjukkan bahwa subjek S2 mengetahui pemberian motivasi yang tepat dan sesuai dengan kebutuhan siswa.

\section{Pengetahuan tentang Siswa}

Subjek S1 berusaha memahami gaya belajar setiap siswa dan berusaha memberikan pembelajaran yang beragam. Subjek S1 mengetahui kesulitan siswa dalam memahami materi melalui hasil belajar serta mengetahui letak kesulitan siswa dalam memahami maksud soal cerita. Sehingga dalam membuat soal cerita harus lebih memperhatikan penggunaan bahasa. Selain itu, faktor lain kesulitan siswa adalah malu bertanya ketika tidak memahami suatu materi yang dijelaskan guru. Subjek 
menyatakan bahwa: "Jadi aku biasanya memberikan pembelajaran yang beragam. ... Dari hasil belajarnya, Nah dari situ bisa dilihat dari soal evaluasi yang kita buat. ... Mereka kadang baca soal saja, belum paham maksud soalnya. ... ada siswa yang malu bertanya di depan teman-temannya”. Hal ini menunjukkan bahwa subjek S1 mengetahui kesulitan yang dialami siswa namun subjek S1 belum maksimal memberikan pembelajaran yang sesuai dengan karakteristik gaya belajara setiap siswa.

Subjek S2 kurang memperhatikan gaya belajar siswa dengan tetap memberikan pembelajaran seperti biasa karena lebih memfokuskan pada pencapaian tujuan pembelajaran. Subjek S2 mengetahui kesulitan siswa dalam memahami materi melalui tanya jawab dikelas dengan tujuan jika terdapat siswa yang belum paham maka dapat bertanya terlebih dahulu sehingga siswa tersebut tidak ketinggalam materi. Selain itu, Subjek S2 juga mengetahui letak kesulitan siswa dalam operasi hitung yang masih kurang. Subjek menyatakan bahwa: "jadi kebanyakan kita mengajar seperti biasa, kembali lagi kita punya tuntutan harus menyampaikan tujuan pembelajaran supaya bisa tercapai. ... Takutnya, kita sudah terlalu jauh mengajar tapi materi sebelumnya belum dipahami, akhirnya kita tekankan kalau yang belu paham silahkan bertanya ... kesulitannya misalkan pada penjumlahan harus menyamakan penyebutnya". Hal ini menunjukkan bahwa subjek S2 mengetahui kesulitan yang dialami siswa namun kurang memperhatikan gaya belajar siswa dengan lebih memfokuskan pada tujuan pembelajaran yang akan dicapai.

Subjek S1 menyampaikan konsep pembelajaran dengan menghubungkan materi pembelajaran dengan kehidupan sehari-hari. Subjek menyatakan bahwa: "kalau aku sebelum masuk materi pembelajaran itu sebisa mungkin kita kaitkan konsep tersebut dengan kehidupan sehari-hari”. Hal ini menunjukkan bahwa subjek S1 lebih menekankan pada pembelajaran yang kontekstual dalam menyampaikan konsep pembelajaran.

Subjek S2 menyampaikan konsep pembelajaran dengan menghubungkan konsep pembelajaran dengan lingkungan siswa. Subjek menyatakan bahwa: "Kita memberikan contoh yang bener-bener deket dengan lingkungannya. Jadi mereka kalau mau membayangkan itu mudah”. Hal ini menunjukkan bahwa subjek S2 lebih menekankan pda pembelajaran yang kontekstual dalam menyampaikan konsep pembelajaran.

\section{Pengetahuan tentang Sumber Daya}

Subjek S1 melakukan analisis materi dengan cara memilah materi yang mudah, sedang dan susah agar subjek S1 mengetahui letak kelemahan siswa. Sumber materi yang digunakan subjek S1 berpedoman pada buku guru dan internet. Manfaat dari sumber materi yang digunakan untuk mempermudah guru dan siswa. Subjek menyatakan bahwa: "kita harus memilah tingkatan materi mudah, sedang dan sukar agar kita tau kelemahan siswanya di materi yang mana. ... buku lebih akurat, dan tambahannya bisa mencari di internet sehinga lebih mempermudah guru dan siswa". Hal ini menunjukkan bahwa subjek S1 mengetahui sumber daya berupa materi dan sumber belajar.

Subjek S2 menyusun materi dengan berpedoman pada buku untuk mengetahui bagian materi yang 
perlu ditekankan kepada siswa. Sumber materi yang digunakan oleh subjek S2 adalah buku guru, buku siswa dan internet. Subjek menyatakan bahwa: "Kalau nyusun materi iya sih, tapi kita lebih mengacu ke buku. ... supaya kita tau materi yang perlu ditekankan lebih kepada siswa. ... Nyari di internet selain buku guru dan buku siswa”. Hal ini menunjukkan bahwa subjek S2 mengetahui sumber daya berupa materi dan sumber belajar.

Subjek S1 membuat media pembelajaran yang berpedoman pada buku dan dimodifikasi untuk menarik perhatian siswa sehingga siswa dapat dengan mudah memahami materi. Ketika ditanya mengenai pengembangan media pembelajaran, subjek mengatakan bahwa: "Kalau merombak banget sih tidak, tapi paling yah memodifikasi sedikit. Dibuku sudah ada tinggal aku tambahin sedikit. ... Untuk memper mudah materi agar mereka cepat paham”. Hal ini menunjukkan bahwa subjek S1 mengetahui sumber daya berupa media pembelajaran yang sesuai dengan materi.

Subjek S2 mengembangkan media dengan berpedoman pada buku untuk mempermudah siswa dalam memahami materi pembelajaran. Selain itu, manfaat dari media pembelajaran yang dibuat dapat menarik bagi siswa. Siswa tidak hanya mendengarkan dan membayangkan tetapi bisa mempraktikkannya secara langsung. Subjek menyatakan bahwa: "Kalau pengembangan media yang paling jelas itu tadi kalau dari buku. ... yah itu tadi untuk mempermudah siswa memahami materi pembelajaran. ... menarik bagi siswa, yang tadinya hanya mendengarkan dan membayangkan bisa buat sendiri, bisa memahami dan praktek langsung”. Hal ini menunjukkan bahwa subjek S2 mengetahui sumber daya berupa media pembelajaran yang sesuai dengan materi.

\section{Pengetahuan tentang Tujuan}

Subjek S1 membuat tujuan pembelajaran yang dibuat sebaiknya dikaitkan dengan kehidupan sehari-hari. Implementasi tujuan pembelajaran oleh subjek S1 tergantung pada materi yang dibahas sehingga bisa digunakan didunia nyata. Namun kenyataannya tidak semua materi dapat dikaitkan dengan dunia nyata. Ketika ditanya mengenai kaitan tujuan dengan kehidupan nyata, subjek menyatakan bahwa: "Misal yah pas IPA belajar mencangkok, tujuannya untuk digunakan dalam kehidupan sehari-hari. Keuntungannya pohonnya bisa mudah berbuah atau dan lain-lain. ... Kadang ada yang bisa dikaitkan ke kehidupan sehari-hari dan ada yang tidak bisa dikaitkan dengan kehidupan sehari-hari”. Hal ini menunjukkan bahwa subjek S1 dapat menyampaikan tujuan pembelajaran dan membantu siswa untuk mengimplementasikan tujuan pembelajaran dalam kehidupan.

Subjek S2 membuat tujuan pembelajaran yang dikaitkan dengan kehidupan sehari-hari yang dikemas secara nyata. Namun subjek mengalami keuslitan ketika materi yang dibahas tidak dapat dimplementasikan ke dunia nyata. Subjek menyatakan bahwa: "Sebisa mungkin untuk tujuannya supaya pembelajaran yang kita kemas itu dekat dengan kehidupan mereka. ... kadang ada materi yang relevan dengan kehidupan sehari-hari dan ada juga yang tidak dan itu susah untuk membuat tujuannya kekehidupan nyata dan itu susahnya". Hal ini menunjukkan bahwa subjek S2 dapat menyampaikan tujuan pembelajaran dan membantu siswa untuk mengimplementasikan tujuan 
pembelajaran dalam kehidupan.

\section{Pengetahuan tentang Materi}

Subjek S1 merangkum pembelajaran dengan cara proses tanya jawab yang diakhiri dengan pemberian penekanan pada hal yang penting. Subjek S1 juga membuat mind mapping untuk meringkas materi pokok sehingga memudahkan siswa dalam belajar dan mengingat materi. Subjek S1 menyatakan bahwa: "Biasanya aku itu kalau diakhir pembelajaran ada tanya jawab, Jadi akhirnya aku beri penekanan pada materi apa. ... Biasanya kalau aku ada materi yang penting aku buat kaya mind maping, jadi siswa juga aku minta buat seperti itu juga”. Hal ini menunjukkan bahwa subjek S1 merangkum materi pembelajaran yang dianggap penting dalam bentuk mind mapping untuk membantu siswa dalam mengingat materi.

Subjek S2 merangkum pembelajaran dengan cara menekankan secara berulang hal penting pada materi terkait dan membuat soal evaluasi berdasarkan materi. Subjek S2 membuat mind mapping untuk membantu siswa dalam proses pembelajaran. Tetapi mind mapping yang dibuat subjek S2 hanya pada materi IPS. Subjek menyatakan bahwa: "Nah itu, lebih kepada materi-materi pokok sih sebenarnya kan kadang materi pokok itu yang lebih sering di ulang guru maksdunya di ulang biar lebih paham. Jadi, kebanyakan soal-soal yang dibuat pada soal evaluasi itu kan sub-sub materi dari materi tersebut. ... Ya, mind mapping waktu itu di kelas 6 hanya pada materi IPS saja”. Hal ini menunjukkan bahwa subjek S2 merangkum materi pembelajaran dengan cara menekankan secara berulang pada bagian terpenting dan membuat mind mapping untuk materi tertentu.

Selain wawancara, kedua subjek juga diberikan soal terkait bilangan dan geometri yang diajarkan pada kelas rendah dan kelas tinggi untuk melihat sejauh mana PCK dari kedua subjek pada pembelajaran matematika.

Ibu mengemas buah duku dengan 4 kantong plastik. Tiap kantong plastik berisi 20 duku. Berapakah jumlah duku yang dikemas ibu?

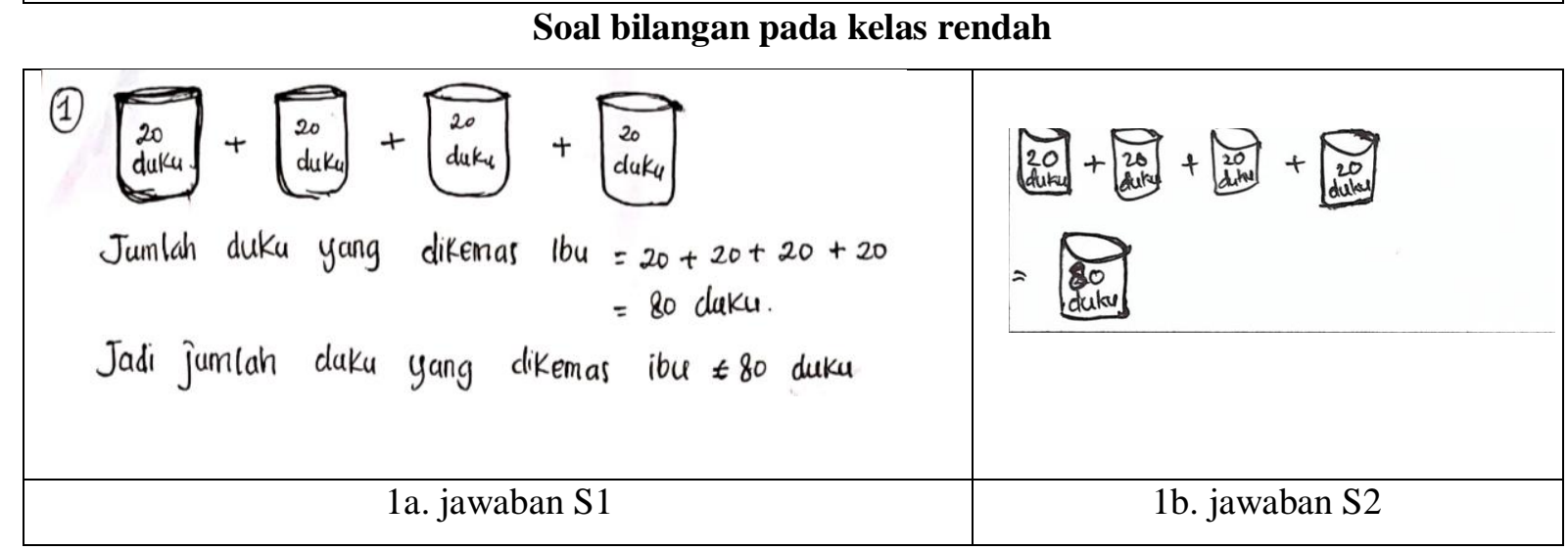

Gambar 1. Jawaban kedua subjek pada soal bilangan pada kelas rendah

Subjek S1 dan subjek S2 mengerjakan soal bilangan pada kelas rendah dengan cara mengilustrasikan soal cerita kedalam bentuk gambar selanjutnya subjek S1 memberikan penjelasan singkat terkait soal dan diberi kesimpulan pada bagian akhir pengerjaan yang ditampilkan pada 
gambar 1a serta menyesuaikan cara pengerjaannya dengan tingkatan kelas. Hal ini menunjukkan bahwa pengetahuan pada pembelajaran matematika, subjek S1 dikatakan baik karena telah memenuhi komponen pada pengetahuan tentang mengajar dan pengetahuan tentang siswa.

Subjek S2 mengerjakan soal bilangan pada kelas rendah dengan mengutamakan pada hasil akhir tanpa memberikan kesimpulan pada bagian akhir pengerjaan yang ditampilkan pada gambar $1 \mathrm{~b}$ sehingga proses pengerjaan yang dilakukan subjek S2 tidak terstruktur. Namun subjek sudah mampu menyesuaikan pengajaran pada tingkatan kelas. Hal ini menunjukkan bahwa pengetahuan pada pembelajaran matematika, subjek S2 dapat dikatakan cukup karena telah memenuhi komponen pada pengetahuan tentang mengajar dan pengetahuan tentang siswa meskipun belum maksimal.

Setiap hari senin, SMP Jambu mengadakan upacara bendera. Halaman yang digunakan untuk upacara berbentuk persegi panjang. Panjangnya 25 meter dan lebarnya 20 meter. Berapakah keliling halaman tersebut?

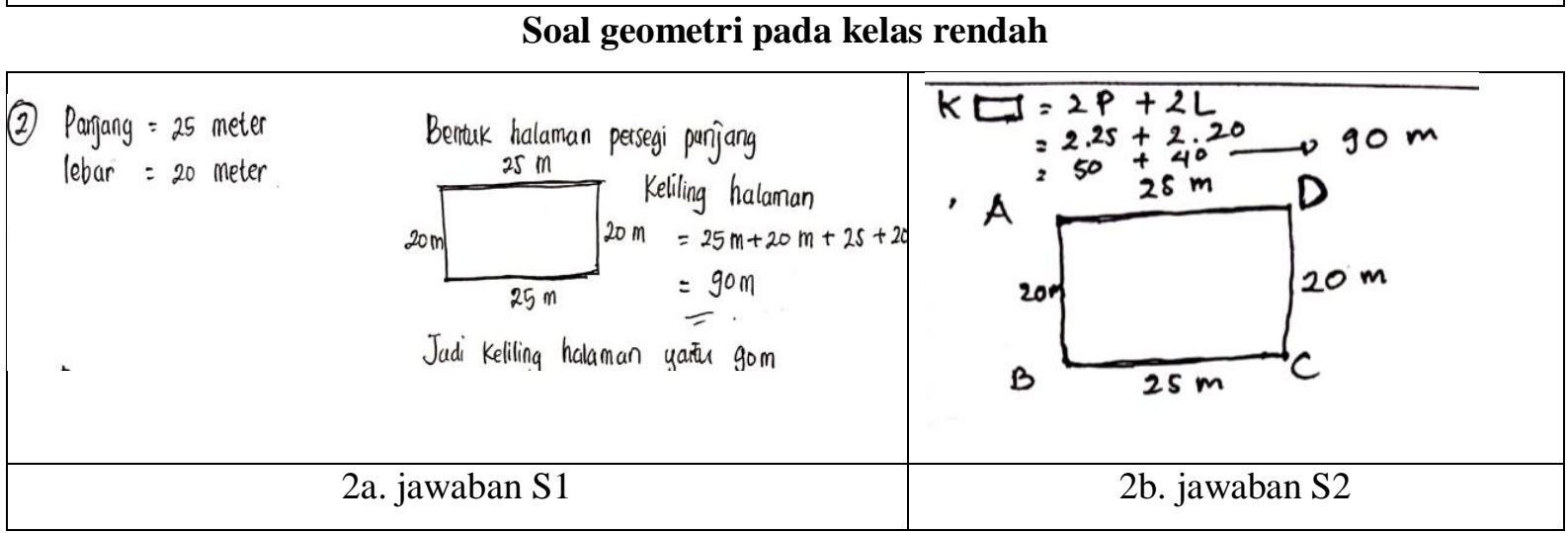

\section{Gambar 2. Jawaban kedua subjek pada soal geometri pada kelas rendah}

Subjek S1 menekankan konsep keliling terlebih dahulu sebelum memberikan soal lanjutan kepada siswa. Terlihat ketika subjek S1 mengerjakan soal geometri pada kelas rendah dimana subjek S1 mengerjakan soal dengan menggunakan operasi penjumlahan serta pada akhir pengerjaan subjek S1 memberikan kesimpulan yang ditampilkan pada gambar 2a serta menyesuiakan dengan tingkatan kelas. Hal ini menunjukkan bahwa pengetahuan pada pembelajaran matematika subjek S1 dikatakan baik karena telah memenuhi komponen pada pengetahuan tentang mengajar dan pengetahuan tentang siswa.

Subjek S2 mengerjakan soal geometri pada kelas rendah dengan konsep keliling dimana menggunakan operasi perkalian, tetapi belum menggunakan rumus keliling. Subjek S2 menjelaskan konsep dasar keliling kepada siswa yang ditampilkan pada gambar $2 b$. Terlihat pada gambar $2 b$, subjek S2 dalam pengerjaannya tidak terstruktur. Oleh karena itu, pengetahuan pada pembelajaran matematika subjek S2 dapat dikatakan cukup karena telah memenuhi komponen pada pengetahuan tentang mengajar dan pengetahuan tentang siswa meskipun belum maksimal.

Bella pergi ke perpustakaan setiap 4 hari sekali, sedangkan Yosia setiap 6 hari sekali. Jika mereka pergi ke perpustakaan sama-sama pada hari Rabu, pada hari apa mereka pergi ke perpustakaan 
bersama-sama lagi?

\section{Soal bilangan pada kelas tinggi}

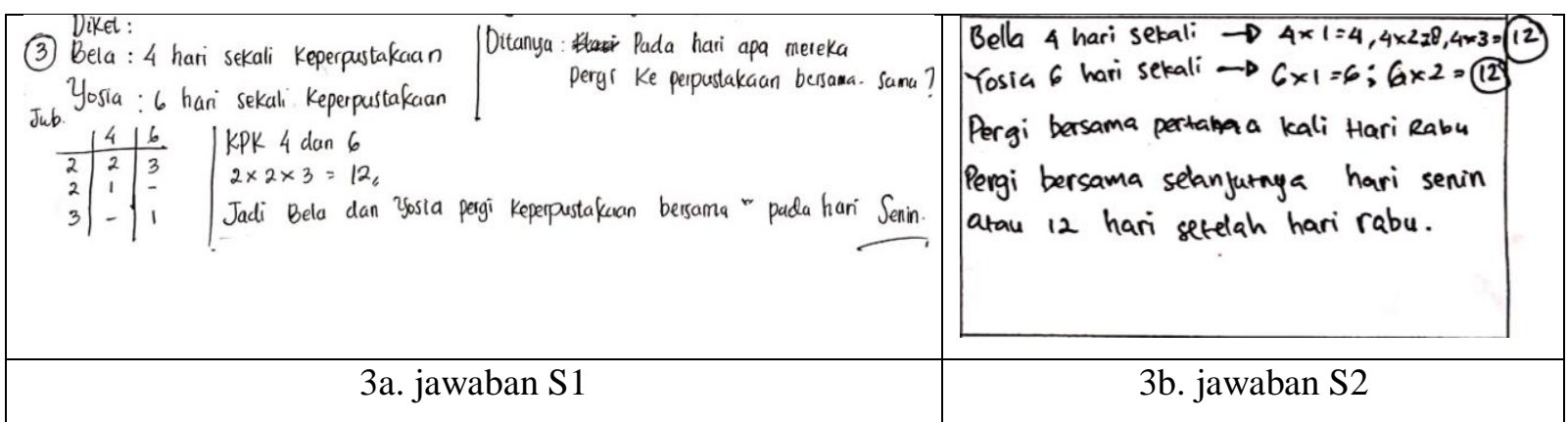

\section{Gambar 3. Jawaban kedua subjek pada soal bilangan pada kelas tinggi}

Subjek S1 mengerjakan soal bilangan pada kelas tinggi menggunakan cara tabel lalu selanjutnya dikerjakan menggunakan konsep KPK. Setelah memperoleh hasilnya subjek S1 memberikan kesimpulan pada bagian akhir pengerjaannya yang ditampilkan pada gambar 3a. Dalam pengerjaannya subjek S1 dapat menyesuaikan cara mengerjakan soal sesuai tingkatan kelas tinggi serta lebih terstruktur. Hal ini menunjukkan bahwa pengetahuan pada pembelajaran matematika, subjek S1 dikatakan baik karena telah memenuhi komponen pada pengetahuan tentang mengajar dan pengetahuan tentang siswa.

Subjek S2 mengerjakan soal bilangan pada kelas tinggi menggunakan konsep KPK dengan cara mengalikan setiap bilangan dengan urutan bilangan yang dimulai dari satu hingga keduanya memiliki hasil yang sama ditunjukkan pada Gambar 3b. Namun cara yang diberikan oleh subjek S2 kurang memungkinkan ketika bilangan pada soal lebih besar. Subjek S2 mengerjakan soal menggunakan konsep dasar dengan cara termudah dan kurang terstruktur. Hal ini menunjukkan bahwa pengetahuan pada pembelajaran matematika, subjek S2 dapat dikatakan cukup karena telah memenuhi komponen pada pengetahuan tentang mengajar dan pengetahuan tentang siswa meskipun belum maksimal.

Pak Dilan mempunyai sebidang kebun berbentuk persegi panjang dengan ukuran $9 \mathrm{~m}$ x $7 \mathrm{~m}$. Sebagian kebun tersebut akan dibuat kolam ikan berbentuk persegi dengan ukuran $5 \mathrm{~m}$. Berapa luas kebun pak Dilan yang tidak dibuat kolam ikan?

\section{Soal geometri pada kelas tinggi}




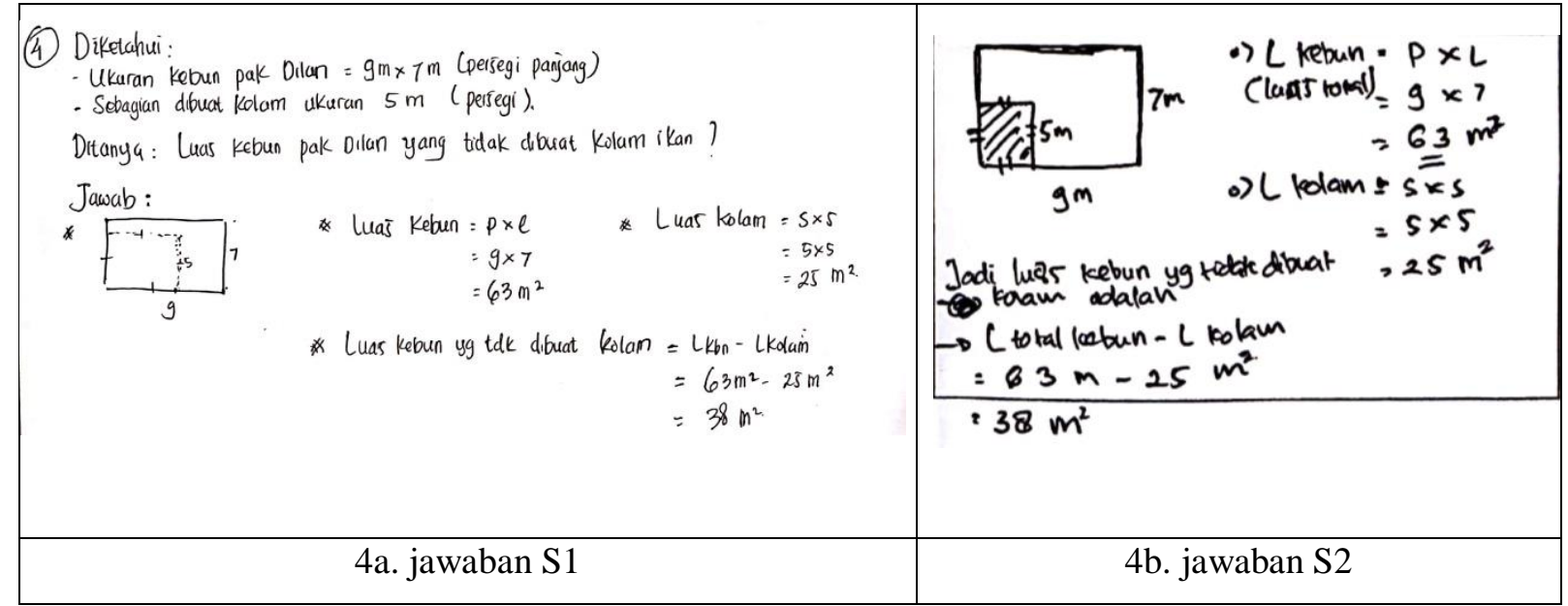

Gambar 4. Jawaban kedua subjek pada soal geometri pada kelas tinggi

Gambar 4a merupakan jawaban yang diberikan oleh subjek S1 yang mana dikerjakan secara terstruktur meskipun pada bagian akhir kemungkinan subjek lupa untuk memberikan kesimpulan. Hal ini menunjukkan bahwa pengetahuan pada pembelajaran matematika subjek S1 dikatakan baik karena telah memenuhi komponen pada pengetahuan tentang mengajar dan pengetahuan tentang siswa.

Gambar 4b merupakan jawaban yang diberikan oleh subjek S2 yang mana dikerjakan secara tidak terstruktur meskipun mencantumkan kesimpulan pada akhir pengerjaan. Namun pengerjaan yang di lakukan subjek S2 sudah mampu menyesuaikan pada tingkatan kelas tinggi. Hal ini menunjukkan bahwa pengetahuan pada pembelajaran matematika, subjek S2 dapat dikatakan cukup karena telah memenuhi komponen pada pengetahuan tentang mengajar dan pengetahuan tentang siswa meskipun belum maksimal.

\section{PEMBAHASAN}

Kompetensi pedagogik ditunjukkan dari 5 komponen PCK yang meliputi pengetahuan tentang kurikulum, penilaian, mengajar, siswa, dan sumber daya.

\section{Pengetahuan tentang Kurikulum}

Pada pengetahuan kurikulum subjek S1 dapat mengetahui letak perbedaan KTSP dan Kurikulum 2013 tematik sehingga subjek lebih memilih menggunakan KTSP. Subjek juga mengetahui struktur pembuatan RPP yang mengacu pada Kurikulum 2013 tematik dengan mengaitkan pembelajaran pada kehidupan sehari-hari. Subjek S2 dapat mengetahui letak perbedaan KTSP dan Kurikulum 2013 tematik sehingga subjek memilih menggunakan Kurikulum 2013 tematik. Subjek mengetahui struktur pembuatan RPP yang mengacu pada Kurikulum 2013 tematik dengan menyesuaikan tujuan pembelajaran dengan alokasi waktu. Oleh karena itu, kedua subjek dapat dikatakan telah memiliki pengetahuan tentang kurikulum yang baik. Hal ini sejalan dengan Mastur (2017) bahwa RPP yang dibuat berpedoman pada konsep kurikulum 2013, kemudian RPP dikembangkan dengan mengacu pada standar isi dan silabus serta menggunakan pendekatan saintifik.

\section{Pengetahuan tentang Penilaian}

Pada pengetahuan tentang penilaian subjek S1 telah memahami struktur penilaian pada setiap 
aspek penilaian dan memberikan evaluasi berupa remedial dengan tujuan untuk memperbaiki nilai. Subjek S2 telah memahami struktur penilaian pada setiap aspek penilaian. dan memberikan evaluasi berupa remedial dengan tujuan untuk mendapatkan nilai yang lebih tinggi dari sebelumnya. Oleh karena itu, kedua subjek dapat dikatakan telah memiliki pengetahuan tentang penilaian yang baik. Hal ini didukung oleh Permendikbud Nomor 23 tahun 2016 tentang standar penilaian bahwa penilaian merupakan proses pengumpulan dan pengelolahan informasi untuk mengukur pencapaian hasil belajar peserta didik.

\section{Pengetahuan tentang Mengajar}

Pada pengetahuan tentang mengajar subjek S1 dapat memberikan pengajaran dengan menyesuaikan keadaan siswa dan memberikan motivasi sesuai kebutuhan siswa. Dalam menjawab soal matematika tentang bilangan dan geometri subjek S1 memperlihatkan pengetahuan tentang mengajar dimana subjek menjawab soal secara terstruktur dan menyesuaikan pada tingkatan kelas. Subjek S2 menyesuaikan model pembelajaran sesuai dengan materi dan pemberian motivasi yang tepat sesuai dengan kebutuhan siswa. Selain itu, dalam menjawab soal matematika tentang bilangan dan geometri subjek S2 memperlihatkan pengetahuan tentang mengajar dimana subjek menjawab soal secara tidak terstruktur namun sudah menyesuaikan pada tingkatan kelas. Oleh karena itu, subjek S1 dapat dikatan telah memiliki pengetahuan tentang mengajar yang baik. Sedangkan subjek S2 dapat dikatakan memiliki pengetahuan tentang mengajar yang cukup. Hal ini sejalan dengan penelitian Suryana (2013) bahwa pengetahuan mengajar guru meliputi strategi pembelajaran, sikap dan motivasi mempengaruhi hasil belajar siswa.

\section{Pengetahuan tentang Siswa}

Pada pengetahuan tentang siswa subjek S1 telah mengetahui letak kesulitan belajar yang dialami siswa namun belum maksimal dalam memberikan pembelajaran sesuai gaya belajar setiap siswa. Selain itu, subjek S1 menekankan pada pembelajaran kontekstual dalam menyampaikan konsep pembelajaran. Dalam menjawab soal matematika tentang bilangan dan geometri subjek S1 memperlihatkan pengetahuan tentang siswa dimana subjek menjawab soal secara terstruktur sehingga membiasakan siswa dalam menjawab soal secara sistematis dan memberikan pengerjaan soal menyesuaikan pada tingkatan kelas. Subjek S2 telah mengetahui letak kesulitan belajar yang dialami siswa namun kurang memperhatikan gaya belajar siswa dengan lebih memfokuskan pada tujuan pembelajaran yang akan dicapai dan lebih menekankan pada pembelajaran kontekstual dalam menyampaikan konsep pembelajaran. Dalam menjawab soal matematika tentang bilangan dan geometri subjek S2 memperlihatkan pengetahuan tentang siswa dimana subjek menjawab soal secara tidak terstruktur sehingga ditakutkan membiasakan siswa dalam menjawab soal secara tidak sistematis dan memberikan pengerjaan soal menyesuaikan pada tingkatan kelas. Oleh karena itu, subjek S1 dapat dikatan telah memiliki pengetahuan tentang siswa yang baik. Sedangkan subjek S2 dapat dikatakan memiliki pengetahuan tentang siswa yang cukup. Amir (2015) mengatakan bahwa dalam memecahkan suatu masalah guru harus lebih memperhatikan proses berpikir siswa berdasarkan gaya 
belajar karena setiap siswa memiliki karakteristik proses berpikir dan gaya belajar yang berbeda.

\section{Pengetahuan tentang Sumber Daya}

Pada pengetahuan tentang sumber daya, subjek S1 telah mengetahui materi dan sumber belajar yang digunakan serta menyesuaikan media pembelajaran dengan materi. Subjek S2 telah mengetahui materi dan sumber belajar yang digunakan serta menyesuaikan media pembelajaran dengan materi. Oleh karena itu, kedua subjek dapat dikatakan telah memiliki pengetahuan tentang sumber daya yang baik. Hal ini sejalan dengan Setiawan, dkk (2018) bahwa media pembelajaran yang digunakan guru menyesuaikan dengan fasilitas yang disediakan oleh sekolah dan sumber belajar menggunakan buku.

Kompetensi profesional ditunjukkan dari 2 komponen PCK yang meliputi penegtahuan tentang tujuan dan materi.

\section{Pengetahuan tentang Tujuan}

Pada pengetahuan tentang tujuan, subjek S1 dapat tujuan pembelajaran dan membantu siswa untuk mengimplementasikannya dalam kehidupan. Subjek S2 dapat tujuan pembelajaran dan membantu siswa untuk mengimplementasikannya dalam kehidupan. Oleh karena itu, kedua subjek dapat dikatakan telah memiliki pengetahuan tentang tujuan yang baik. Hal ini sejalan dengan penelitian Margiyono dan Mampouw (2011) guru memperhatikan urutan materi pembelajaran yang logis serta memahami setiap tujuan pembelajaran yang dibuatnya dan aplikasinya di dalam kehidupan seharihari.

\section{Pengetahuan tentang Materi}

Pada pengetahuan tentang materi, subjek S1 merangkum materi pembelajaran yang dianggap penting untuk membantu siswa dalam mengingat materi. Subjek S2 merangkum materi pembelajaran dengan cara menekankan secara berulang pada bagian terpenting. Dalam menyelesaikan soal matematika tentang bilangan dan geometri kedua subjek bisa membedakan setiap soal sesuai materi pada tingkatannya. Oleh karena itu, kedua subjek dapat dikatakan telah memiliki pengetahuan tentang materi yang baik. Hal ini sejalan dengan Untari (2013) bahwa pemahaman konsep pada pembelajaran matematika sebaiknya guru mengajarkan konsep dengan menekankan sifat-sifat dari definisi serta menekankan contoh-contoh soal sesuai konsep materi.

\section{KESIMPULAN}

Kompetensi pedagogik yang dimiliki oleh guru dapat dikatakan baik pada pembelajaran matematika. Hal ini terlihat pada pengetahuan tentang kurikulum, penilaian, mengajar, siswa dan sumber daya yang dapat dikatakan baik. Kompetensi profesional yang dimiliki oleh guru dapat dikatakan baik pada pembelajaran matematika. Hal ini terlihat pada pengetahuan tentang tujuan dan materi yang dapat dikatakan baik. Oleh karena itu, PCK yang dimiliki guru sudah baik dalam pembelajaran matematika.

Kompetensi pedagogik yang dimiliki oleh calon guru dapat dikatakan cukup baik pada pembelajaran matematika. Hal ini terlihat pada pengetahuan tentang kurikulum, penilaian, dan sumber daya yang dapat dikatakan baik. Namun pada pengetahuan tentang mengajar dan siswa, calon guru 
dapat dikatakan cukup baik. Oleh karena itu, PCK yang dimiliki calon guru cukup baik dalam pembelajaran matematika.

\section{DAFTAR PUSTAKA}

Amir, Mohammad F. (2015). Proses Berpikir Kritis Siswa Sekolah Dasar Dalam Memecahkan Masalah Berbentuk Soal Cerita Matematika Berdasarkan Gaya Belajar. Jurnal Math Education Nusantara.

Margiyono, Iis., \& Mampouw, Helti L. (2011). Deskripsi Pedagogical Content Knowledge Guru Pada Bahasan Tentang Bilangan Rasional. Proceeding Building the Nation Character through Humanistic Mathematics Education.

Maryono. (2016). Profil Pedagogical Content Knowledge Mahasiswa Calon Guru Matematika Ditinjau dari Kemampuan Akademiknya. JURNAL REVIEW PEMBELAJARAN MATEMATIKA, 1(1), 1-16. http://doi.org/10.26877/bioma.v5i1.1496

Mastur. (2017). Implementasi Kurikulum 2013 Dalam Pelaksanaan Pembelajaran Di SMP. Jurnal Inovasi Teknologi Pendidikan

Menteri Pendidikan dan Kebudayaan RI. (2018). Permendikbud Republik Indonesia Nomor 15 Tahun 2018 Tentang Pemenuhan Beban Kerja Guru, Kepala Sekolah dan Pengawas Sekolah.

Menteri Pendidikan dan Kebudayaan RI. (2007). Permendiknas Nomor 16 tahun 2007 tentang Standar Kualifikasi Akademik dan Kompetensi Guru, 1-32.

Menteri Pendidikan dan Kebudayaan RI. (2016). Permendiknas Nomor 23 tahun 2016 tentang Standar Penilaain Pendidikan.

Nurhidayah, D. A. (2016). Analisis Faktor Kesulitan Belajar Matematika Siswa SMA Pada Implementasi Kurikulum 2013, 1-12.

Paramita, Rahardian P. (2018). Rapor Guru dalam Hasil Uji Kompetensi. Beritagar.id. (online), (file:///C:/Users/TOSHIBA/Documents/Materi\%20Kuliah/semester\%206/jurnal\%20TA1/TA1/b ahan\%20TA/Rapor\%20guru\%20dalam\%20hasi1\%20uji\%20kompetensi.html), diakses 1 Mei 2019.

Purwianingsih, W., Rustamand, N. Y., \& Redjeki, S. (2010). Pengetahuan Konten Pedagogi ( PCK ) dan Urgensinya dalam Pendidikan Guru. Jurnal Pengajaran MIPA, 16(2), 87-94.

Rozano, D. (2010). Menggagas pendidikan dasar dan menengah. Jurnal Saung Guru, 1(2), 51-65.

Rusilowati, Ani., Hartono., \& Supriyadi. (2012). Pengembangan Model Pembelajaran Better Teaching And Learning Berkarakter Untuk Membekali Kompetensi Pedagogi Mahasiswa Calon Guru. Jurnal Penelitian Pendidikan.

Sanjaya, Wina. (2010). Kurikulum dan Pembelajaran: Teori dan Praktik Pengembangan kurikulum Tingkat Satuan Pendidikan (KTSP). Jakart. Kencana Prenadamedia Group.

Sanjaya, Wina. (2006). Strategi Pembelajaran Berorientasi Standar Proses Pendidikan. Jakarta. Kencana Prenadamedia Group. 
Setiawan, Usup., Maryani, Enok., \& Nandi. (2018). Pedagogical Content Knowledge(PCK) Guru Geografi SMA. Jurnal Ilmiah Ilmu Sosial.

Shulman, L. S. (n.d.). Those Who Understand: Knowledge Growth in Teaching. Educational Researcher, 15(2), 4-14. http://doi.org/10.3102/0013189x015002004

Suryana, Dadan. (2013). Pengetahuan tentang Strategi Pembelajaran, Sikap, dan Motivasi Guru. Jurnal Ilmu Pendidikan Universitas Negeri Malang.

Turnuklu, E. B., \& Yesildere, S. (2007). The Pedagogical Content Knowledge in Mathematics: Preservice Primary Mathematics Teachers' Perspectives in Turkey. IUMPST: The Journal, 1(October), 1-13.

Untari, Erny. (2013). Diagnosis Kesulitan Belajar Pokok Bahasan Pecahan Pada Siswa Kelas V Sekolah Dasar. Jurnal Ilmiah STKIP PGRI Ngawi.

Wulandari, M., \& Iriani, A. (2018). Pengembangan Modul Pelatihan Pedagogical Content Knowledge (PCK) Dalam Meningkatkan Kompetensi Profesional dan Kompetensi Pedagogik Guru Matematika SMP. Kelola: Jurnal Manajemen Pendidikan, 5(2), 177-189. 